\title{
Güçlü Kent Markası Oluşturmada Destinasyon Kişiliği, Bilişsel ve Duygusal İmajın Rolü: Hatay Örneği
}

\author{
The Role of Destination Personality, Cognitive Image and Affective Image in \\ Strong City Branding: The case of Hatay
}

\author{
Prof. Dr. Tülin Ural - Ebru Tercan - Öğr. Grv. Müzeyyen Arslan - Demet Taner
}

\begin{abstract}
Öz
Bu araştırma, bir kentin bilişsel imajı, duygusal imajı ve destinasyon kişiliğinin, turistlerin kenti başkasına tavsiye etme davranışına oransal etkilerini açıklamayı amaçlamaktadır. Araştırma aynı zamanda bu etkilerin, turistlerin kenti ziyaret etme sıklı̆̆ 1 ve amaçlarına göre oluşan alt gruplarda farkllilk gösterip göstermediğini test etmektedir. Alan çalışmasl, Hatay’n üç turistik ilçesi olan Antakya, Defne ve Samandağda Nisan 2015' te yürütülmüştür. Veriler; otel, hava limanı ve tarihsel mekânlarda bulunan 244 turistten toplanmiştır. Verilerin analizi sonucunda, duygusal marka imajı ve destinasyon kişiliğinin kenti arkadaş ve akrabalara tavsiye etme niyetine pozitif etkisi olduğu bulgusuna ulaşılmıştır. Bu ilişkide, duygusal marka imajının etkisi, destinasyon kişiliğinin etkisine oranla daha fazladir. Bölümleme temelli analizde, hem ilk kez hem de tekrar tatil amaçl seyahat edenlerde, bilisssel imaj, tavsiye etme niyetini etkileyen tek anlaml değişkendir. İlk kez iş seyahati ve diğer amaçlarla gelenlerde ise, duygusal imaj etkili olmaktadır. Ancak iş seyahati için tekrar gelenlerde destinasyon kişiliğinin duygusal imajdan daha önemli olduğu bulunmuştur. Yeni yerler görme amacıyla ilk kez gelenlerde duygusal imaj tek anlaml değişken iken tekrarlayan gelişlerde destinasyon kişiliği öne çıkmaktadır.
\end{abstract}

Anahtar Kelimeler: Yer Markalama, Destinasyon Kişiliği, Bilişsel İmaj, Duygusal İmaj, Ağızdan Ağza İletişim

\begin{abstract}
This study aims to explain the relative effects of the cognitive image, affective image and destination personality of a city brand on the visitors' intent to recommend $\mathrm{Ha}$ tay. Additionally, the research has tested whether these effects differ from a subgroup to another group which is segmented based on visiting frequency and visiting purpose of a tourist. The research has been conducted in the various tourism places, Antakya, Defne and Samandağ, in Hatay throughout April, 2015. Data has been obtained from 244 tourists who are at the hotels, airport and historical places. The findings of research regarding whole sample show that affective image of city brand and its destination personality variables influence to the intent to recommend to friends and relatives to city. In this relationship, the effect of the affective image is dominant relative to the effect of destination personality. The segment-base analyses among either first time visitors or repeat visitors traveling for holiday purpose show that cognitive image is the only significant variable influencing the intent to recommend. Among first timevisitors traveling for business purpose or other purpose, affective image significantly influences the visitors' intent to recommend the city. However, for repeat visitors traveling for business purpose, destination personality is becoming more important than affective image. For first time visitors traveling to experience new things, while affective image is the only significant predictor, for those repeat visitors, destination personality comes out.
\end{abstract}

Keywords: Place Branding, Destination Personality, Cognitive Image, Affective Image, Word of Mouth

Prof. Dr. Tülin Ural, Mustafa Kemal Üniversitesi İ̈BF, tulin-ural@hotmail.com Ebru Tercan, Mustafa Kemal Üniversitesi SBE, tercanebru@gmail.com

Öğr. Grv. Müzeyyen Arslan, Mustafa Kemal Üniversitesi SBE, muzeyyenars@hotmail.com

Demet Taner, Mustafa Kemal Üniversitesi SBE, demettaner@hotmail.com 


\section{Giriş}

Son y1llarda turizm sektöründe, güçlü kent markasının oluşturulması ve yönetilmesi, kentlerin çekiciliğini ve rekabet gücünü belirleyen en önemli faktörlerden biri olarak kabul edilmektedir (Noni vd., 2014, s. 218-226). Güçlü marka, ürün ve hizmetlerin rekabet üstünlügü elde etmek, ürünle ilgili riskleri azaltmak, arama maliyetlerini düşürmek, kalite ve değer alg1s1nı yükseltmek ve sonuçta satın alma kararını olumlu yönde etkilemeye katkı sağlamaktadır (Braun-LaTour ve LaTour, 2005, s.19-30). Markalamanin bu yararlarından dolayı birçok kamu kuruluşu ve özel sektör yatırımcıları potansiyel ziyaretçiler arasında olumlu kent imajı yaratmak için çok fazla zaman ve parasal kaynak harcamaktadırlar. Ancak istenilen marka imajının yaratılmasında yaşanan sıkıntılar, yer markalamanın boyutlarının (coğrafik, ekonomik, kültürel, sosyal) çok fazla olması, bu konuyu karmaşılaş̧ırmakta ve halen gerek akademik gerekse pratik yaşamda gündemde tutmaktadır (Landry, 2006; Sevin, 2013).

$\mathrm{Bu}$ araştırmanın amac1; turistlerin gözüyle kent markasının bilişsel ve duygusal imajı ile kentin kişiliğinin kenti başkalarına tavsiye etme davranışına etkilerini tespit etmektir. Bu bağlamda, alt araştırma soruları aşağıdaki gibi belirlenmiştir:

1. Markanın temel bileşenleri olan bilişsel marka imajı, duygusal marka imajı ve destinasyon kişiliğinin kenti başkasına tavsiye etme davranışına etkisi var midır?

2. Var ise, bu boyutların kenti başkasına tavsiye etme davranışını etkileme oranları nedir, ağılıkları farklı mıdır?

3. Bu etkilerin ağırlıkları, farklı amaçla ve farklı sıklıkta kenti ziyaret eden turist gruplarına göre değişmekte midir?

Soruların cevaplarını almak için yapılan araştırmada, Sahin ve Baloğlu tarafından geliştirilen (2014, s. 239-265) kuramsal model temel alınmıştır. Araştırma, akademik yazına sağlayacağ 1 katkı açısından ele alındığında öncelikle, marka boyutlarını dikkate alarak mevcut araştırmalardan daha detaylı ve spesifik bilgiler sunmaktadır. İlave olarak, Sahin ve Baloğlu tarafından geliştirilen model ve bulguların evrensel nitelikte genelleştirilmesine katkı sağlamaktadır.
Sosyal bilimlerde, bir araştırma sonucunda ulaşılan bulguların geçerli olabilmesi ve genelleştirilebilmesi için farklı kültür ve zamanlarda benzer çalışmaların yapılıp aynı sonucu verip vermediğini görmek gerekir (Netemeyer, Bearden ve Sharma, 2003, s. 59-69, Aktaran Kavak B. 2008). Sosyal gerçekliği araştıran çalışma bulgularının ve bunun sonucunda ortaya atılan teorinin, spesifik olma niteliklerinden uzaklaşıp evrenselliğe doğru gitmesinde ve nesnel gerçekliğe ulaşmasında farklı kültür ve zamanlarda, farklı gruplar üzerinde yeniden sınanması çok önemlidir (Baş, T. ve Akturan U. 2008). Bu araştırmanın benzer çalışmalardan fark1; kenti ziyaret edenleri homojen bir kitle olarak kabul etmeyip, gruplara ayırmasıdır. Daha önce yapılan çalışmalarda (örn. Morgan vd., 2004; Ekinci 2007) kenti tüm ziyaret edenler, homojen bir grupmuş gibi ele alınmıştır. Oysaki bu gerçekçi değildir. Şahin ve Baloğlu (2011) ve Uzama (2012) kenti ziyaret eden turist grubunun heterojen olduğunu ve kent hakkındaki söylemlerinin farklı gruplara göre değişebileceğini ifade etmektedirler. Böylelikle, keşifsel nitelikte olan bu araştırmada marka imajı ve tavsiye etme davranışı arasında anlamlı ilişki olduğunu ileri süren teorinin alt gruplarda da geçerli olup olmadığı test edilmektedir. Uygulamada ise, bulguların özellikle Hatay ilinin turizm faaliyetlerini yürüten kamu yöneticileri ve özel sektör turizm yatırımcılarına daha etkili ve karlı faaliyetleri için rehber olacağı umulmaktadır. Böylelikle kente daha fazla turist gelmesi sağlanarak kent ekonomisinin canlanması sağlanabilinecektir.

Araştırmanın öznesi olarak Hatay ili seçilmiştir. Dolayısıyla, il hakkında turizm potansiyeli açısından kısaca bilgi vermekte yarar vardır:

“Akdeniz’in doğu kıyılarında Toroslar’ın güney uzantısı Amanos ile Habib Neccar Dağları́nın önündeki Amik ovasında kurulmuş olan Hatay ilinin merkez ilçesi Antakya, Anadolu'nun en erken yerleşim merkezlerinden birisidir. 2500 yıllık tarihi ile zengin bir kültürel çeşitliliği içinde barındıran Antakya, yüzyıllardır üst üste gelmiş tarih ve kültür katmanlarından oluşmaktadır. Yüzyıllar boyunca Akad, Hitit, Asur, Pers, Roma, Bizans, Emevi, Abbasi ve Osmanlı medeniyetleri bu şehrin kültürel zenginliklerine katkı sağlamıştır. Antakya halkının insanlarla barışık yaşam biçimi ve sosyal kişiliği, bütün bu kültür katmanlarının izdüşümü olarak karşımıza çıkmaktadır. Antakya, tarih boyunca farklı inanç ve kültürlerin iç içe ve barış içinde yaşadığı bir ilçe olarak öne çıkmıştır. Bu zengin kültürel çeşitliliği günümüzde de özenle korumaya ve yaşatmaya çalışmaktadır" (http://www.mku.edu.tr). 
Aşağıda ise fikir vermesi açısından (Resim 1 ve Resim 2); Hatay'ın Antakya ilçesinde yer alan Mozaik Müzesìndeki tarihi koleksiyondan bir örnek ve dünyanın ilk Katolik kilisesi olan Saint Pierre Kilisesi’nin görseli sunulmaktadır (http://www.google.com). .

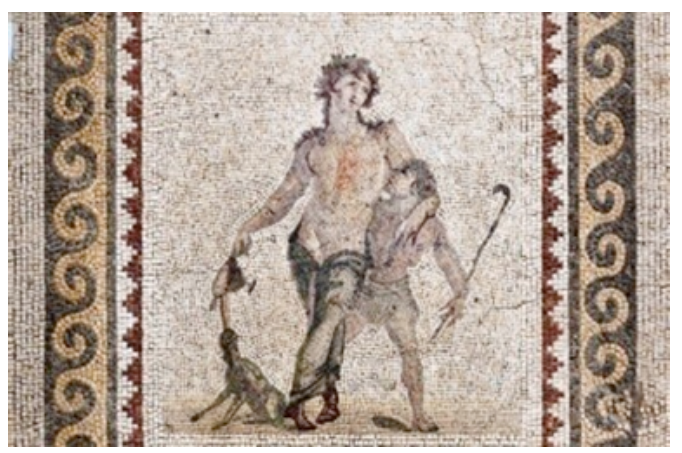

Resim 1. Mozaik Koleksiyonundan Bir Örnek
Bu özellikleriyle Hatay turist çekme açısından büyük bir potansiyele sahiptir. Uygun pazarlama stratejileri ve teknikleri geliştirilerek turist sayısının arttırılması, Hatay halkının refahının artması ve Türkiye'nin ekonomik büyümesi için önemli kazançlar sağlanabilir.

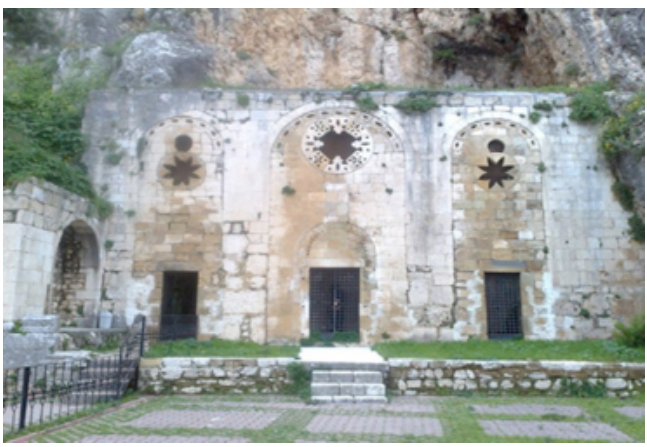

Resim 2. Dünyanın ilk Katolik kilisesi Saint Pierre

\section{Kuramsal Çerçeve}

Marka, ürünler için olduğu kadar coğrafik yerler için de yaratılır. Pazarlama akademik yazınında coğrafik yer bir ürün, kullanıcıları ise müșteri gibi düşünülür (Kavaratzis, 2009, s. 26-37; Merrilees, Miller ve Herington, 2012, s. 1032-1047; Kotler ve Gertner, 2002, s. 249-261). Ancak, yer markalamada etkili olan değişkenlerin çokluğu ve bunlar arasındaki ilişkilerin karmaşıklığı ve çok sayıda farklı sahipliklerin (yerel halk, valilik, belediye, turizm yatırımcıları, seyahat acenteleri, tur operatörleri vb.) olması markalama sürecini ve yönetimini güçleştirmektedir (Sevin, 2014). Yer markası yaratılmasında en önemli bileşenler; bilişsel imaj, duygusal imaj ve destinasyon kişiliği olarak kabul edilmektedir (Ekinci ve diğ., 2007, s. 433446; Morgan vd., 2004). Güçlü yer markası yaratmanın sonucunda kent hakkında olumlu ağızdan ağza iletişim, kenti başkasına tavsiye etmek ya da kişiler arası sohbetlere olumlu yönde konu olmak, önemli marka performans göstergeleridir.

Kent markası bileşenleri olan bilişsel imaj, duygusal imaj ve destinasyon kişiliği boyutları ile kenti başkalarına tavsiye etme niyeti arasındaki ilişkiler oluşturulan kuramsal modelde gösterilmektedir (Şekil 1). Bilişsel imaj, duygusal imaj ve destinasyon kişiliği değişkenlerinin (bağımsız değişkenler) başkalarına tavsiye etme niyetine (bağımlı değişken) etkisi ol- duğunu tez olarak öne süren modelde, bu ilişkilerin ziyaretçilerin gelme sıklığ 1 ve seyahat amacına göre değişiklik gösterebileceği varsayılmaktadır. Modelde yer alan bileşenlerin tanımlamaları ve ilişkilerin teorik alt yapıları şu şekilde açıklanabilir.

Bir yerin marka imajı; "kişi ya da grupların belli bir yer hakkındaki objektif bilgileri, etkilenmeleri, önyargıları, hayalleri ve duygularını ifade eder" (Lawson ve Baud-Bovy; 1977, s. 17). Bir yerin imajının iki temel bileșeni olduğu kabul edilmektedir: Bilişsel imaj ve duygusal imaj (Beerli ve Martin, 2004, s. 623-636). Bilişsel imaj; bir yer hakkındaki bilinçli değerlendirmeler sonucunda oluşan bilgi ve inançlara dair zihinde canlandırılan resimdir. Duygusal imaj ise; bir yer ile ilgili hissedilen duygulardır (Baloğlu ve Brinberg, 1997, s. 11-15). Destinasyon kişiliği; Aaker (1997, s. 347-356) tarafından marka kişiliği temel alınarak "yerin (kentin) insani kişilik özellikleri ile ifade edilmesi” şeklinde tanımlanmaktadır. Nasıl ki bir insanın kişilik özellikleri varsa bir destinasyonun da benzer biçimde kişilik özellikleri vardır. Ağızdan ağza iletişimin tanımı ise şu şekilde yapılmaktadır: Ağızdan ağza iletişim, kişilerin ürün ya da hizmeti diğerlerine olumlu/olumsuz anlatmaların ifade eder.

Akademik yazında, bu bileşenlerin markayı tavsiye etme ya da avukatl lğııı yapma davranışına olumlu et- 
kilerini ortaya koyan çalışmalar mevcuttur. Mendes, Do Valle ve Guerreiro, (2011, s. 366-384), algilanan imaj ile tavsiye etme niyeti arasında pozitif ilişki olduğunu bulmuşlardır. Benzer şekilde; Baloğlu (1999, s. 221-233), Kim, Hallab ve Kim (2012, s. 486-505), destinasyon imajı ve davranışsal niyet arasında ilişki olduğunu ifade etmektedirler. Gonzales ve Bello
(2002, s. 51-85) duygusal marka imajının turistik yeri yeniden ziyaret etme niyetini olumlu yönde etkilediğini ortaya koymaktadırlar. Bagozzi ve Dholakia (2006, s. 45-61) ve Fournier (1998, s. 343-373) duyguların uzun dönemli turist-yer ilişkisini sürdürmeye katkı sağladığını bulmuşlardır.

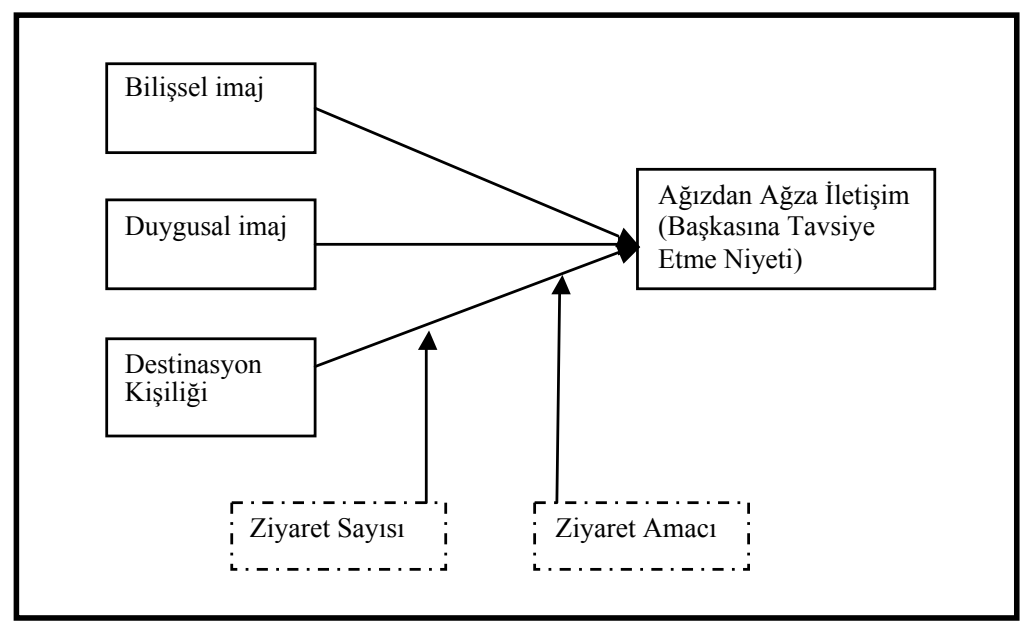

Şekil 1. Araştırmanın Kuramsal Modeli: Bilişsel imaj, Duygusal imaj ve Destinasyon Kişiliği Faktörlerinin Kenti Başkalarına Tavsiye Etme Niyetine Etkileri*

* Bu modelin oluşturulmasında Sahin ve Baloğlu’nun "City Branding: Investigating a Brand Advocacy Model for Distinct Segments, 2014, Journal of Hospitality Marketing \& Management, s.23:3, 239-265 adl eserinden yararlanılmıştır.

Bu bulguların altında yatan temel düşünceler ise şunlardır.

Turizm sektörü bir hizmet sektörü olduğundan somut ürünlere oranla tutundurulması bir hayli güçtür (Fan, 2015, s.1). Soyut olma özelliğinden dolay1 müşterilerin satın almasını sağlamak için ikna etmek gerekir. Bunun için tavsiye etme davranışı önemlidir. Bugünün rekabet dünyasında, kentin avukatlığına soyunan ne kadar çok turist kitlesi elde edebiliyor ise o denli güçlü kent markasının oluşturulabileceği düşünülmektedir. Dolayısıyla stratejik olarak "olumlu söylemler yayma” üzerinde odaklanılması gerekir.

Kişiler, tatillerini planlarken nereye gidecekleri, ne kadar süre kalacakları, hangi turlara katılacakları vb. konularında çoklu kararlar almak durumundadırlar (Fodness ve Murray, 1999, s.220-230). Bu kararlar riskli ve karmaşık olduğundan çeşitli kaynaklardan ek bilgi edinmeye çalışırlar (Sirakaya ve Woodside, 2005, s.815-832). Bu kaynaklar; internet, akraba ve arkadaşlar, reklamlar, oteller, seyahat firmaları, tur operatörleridir. Ağızdan ağza iletişimin reklamlara oranla çok daha güvenilir bilgi kaynağı olduğu yönünde çeşitli çalışmalar mevcuttur. Türkiye'de Alvarez ve Korzay'in (2011, s.425-440) yaptığı araştırmada turistlerin en yaygın kullandığı bilgi kaynağının ağızdan ağza iletişim olduğu bulgusu vurgulanmaktadır.

Turizm sektöründe yığınsal pazarlamadan kişisel pazarlamaya geçiş paradigmasının yükselişi ile birlikte, kent markası oluşturmada pazarın (potansiyel turistlerin) gruplara ayrılarak incelenmesi daha etkin marka stratejilerinin öngörülmesine olanak sağlamaktadir (Pawaskar ve Goel, 2014, s. 255-267). Bu noktadan hareket edilerek; ziyaret edilecek yer seçiminde kişilerin ilk kez gelmesi ile tekrar gelmesi durumunda ya da ziyaret amacina göre (tatil, yeni yerler görme, 
eğlence/heyecan, iş seyahati vb.) bileşenlerin tavsiye etme davranışı üzerindeki etkisinin farklılaşabileceği düşünülmüștür. Gursoy, Bonn ve Chi (2010, s. 340$357)$ ve Sahin ve Baloğlu (2014, s. 239-265) yaptıkları çalışmalarda seyahat amacı ile destinasyon seçimi arasındaki anlamlı ilişkiye dikkat çekmişlerdir. Ancak akademik yazındaki bu saptamalara rağmen farklı koşullardaki turist gruplarında hangi bileşenin ağırlıklı olduğu yönündeki detaylı bilgi yer almamaktadır. Mevcut çalışma, akademik yazındaki bu eksikliği gidermeye çalışmaktadır:

Dolayısıyla, tüm bu söylemlerden yola çıkılarak aşağıdaki hipotezler geliştirilmiştir.

$H_{1}$ : Bilişsel Marka İmajı ve Kenti Başkasına Tavsiye Etme Niyeti arasında pozitif yönlü bir ilişki vardır.

$H_{2}$ : Duygusal Marka İmajı ve Kenti Başkasına Tavsiye Etme Niyeti arasında pozitifyönlü bir ilişki vardır.

$H_{3}$ : Destinasyon Kişiliği ve Kenti Başkasına Tavsiye Etme Niyeti arasında pozitif yönlü bir ilişki vardır.

$\mathrm{H}_{4}$ : Bilişsel Marka İmajı, Duygusal Marka İmajı ve Destinasyon Kişiliği faktörlerinin Kenti Başkasına Tavsiye Etme Niyeti ile ilişkisi; kenti İlk kez/Tekrar Ziyaret Etme Durumu ve Ziyaret Etme Amacina göre oluşan alt gruplarda farklllık göstermektedir.

\section{Araştırma Metodolojisi}

Keşifsel bir niteliğe sahip olan araştırmanın amaçlarına ulaşmak için saptanan model doğrultusunda Hatay'ın turistik ilçelerini ziyaret eden turistlerin görüşleri ve algılamaları değerlemeye alınmıştır. $\mathrm{Bu}$ amaçla modelde yer alan faktörler ölçülmüş ve bu faktörlerin olumlu/olumsuz ağızdan ağza iletișime etkisi sınanmıştır. Çalışmanın bu bölümünde, örneklem seçimi, veri toplama yöntemi, veri analizleri ve araştırma bulgularına yer verilmektedir.

\section{Araştırmanın Ana kütlesi ve Örneklemi}

Araştırmanın anakütlesini, Hatay'ın Antakya, Defne ve Samandağ ilçelerini Nisan ayında ziyaret eden tüm yerli turistler oluşturmaktadır. Bu üç ilçenin seçiminde, tarihsel özellikleri ve turistlerin en çok ziyaret ettikleri alanlar olmaları temel alınmıştır.

Örneklem, "kolayda örnekleme" yöntemi ile belirlenmiştir. Kolayda örnekleme yönteminin seçilme nedeni, ana kütlenin sonsuz olması ve bir örneklem çerçevesine ulaşmanın mümkün olamamasıdır. Araştırmacının elinde anakütle birimlerinin listesi yoksa ya da anakütle hacmi çok büyük ise mümkün olduğunca tesadüfilik sağlanmaya çalışılarak bir örneklem oluşturulabilir. Hatay'in turistik yerleri olan Antakya, Defne ve Samandağ ilçelerini ziyaret edenler üzerine yapılan bu araştırmada otellerde kalanları pratikte her zaman bulmak mümkün olmadığı gibi otel sahipleri de konaklayanların listesini vermemişlerdir. Ziyaret amaçlı gelip de eş, dost ve akrabalarında kalan turistler de bulunmaktadır. Bu durum liste alınsa dahi «kapsam hatasına» yol açar. Kapsam hatası; örneklemin seçildiği listenin (örneklem çerçevesi), araştırmacının ilgilendiği kitlenin (anakütle listesi) tüm üyelerini içermediği zaman oluşur (Baş, T. ve Akturan, U., 2008, s. 13). Dolayısıyla seçilen yöntem kapsam hatasını önlediği için tercih edilmiştir. Yazıcıoğlu ve Erdoğan (2004) olasilıklı olmayan örnekleme yöntemlerinde, araştırmacının örneklemi, anakütleyi temsil yeteneği yüksek ve mümkün olduğunca tesadüfi olarak oluşturabileceğinden söz etmektedirler. Ek olarak; “...... bilinçle seçilmiş örnekler ise anakütle hakkında tesadüfi örneklemeye göre daha gerçekçi sonuçlar verirler" (s.43) demektedirler. Bazı durumlarda zorunlu olarak tesadüfi olmayan örnekleme yöntemlerinin kullanılabileceğinden söz etmektedirler. Bu araştırmada, Basit Tesadüfi Örnekleme yapmak için gerekli olan ve Hatay'ın üç ilçesini ziyaret eden turistlerin listesine ulaşmak mümkün olamamıştır. Kavak'ın (2008, s. 196) Pazarlama ve Pazar Araştırmaları-Tasarım ve Analiz kitabında bu konuda şu bilgiyi vermektedir:

....örneklemin tesadüfi olarak alınabilmesi için, örneklem çerçevesinin ve elemanlarının tam olarak bilinmesi gerekir. Örneğin, Türkiye'deki 5 yıldızlı otel yöneticilerine yönelik bir araştırma yapılıyorsa, söz konusu yöneticilerin tanımlayıcı bilgileriyle beraber bir listesinin bulunması gerekir ki, bu da mümkündür. Ancak 5 yıldızlı otel müşterileri üzerinde bir araştırma için müşterilerin tam listesini bulmak zor olabilir veya zaman alabilir. Öyleyse, böyle bir durumda sonuçları genellenebilir bir kantitatif analiz yapmak mümkün olmaz mı? İşte bu tür durumlar için istatistik bilimindeki bazı kavramların bilinmesi gerekir. Bunların en önemlisi ise Merkezi Limit Teoremidir (Hair, Bush, Ortinau, 2003, s.339). Merkezi Limit Teoremine dayanarak; araştırmac1 elde ettiği verinin normal dağıldığını kanıtlayabilirse, bu veri kıymetlidir ve istatistiki analiz uygulanabilir. Bu veri ile kantitatif analiz yapılabilir ve sonuçlar anakütle için genelleştirilebilir. 
Tesadüfiliği sağlamak ve örneklemin anakütleyi temsil yeteneğini arttırmak için çeşitlendirme yapılarak araştırma sahası; 3 otel, 1 havalimanı ve 2 tarihi mekan olarak belirlenmiştir. Bu mekanların seçiminde ulaşılabilirlik açısından, yerli turistlerin en çok bulunduğu ve konaklama kapasitesi büyük olan noktalar olması temel alınmıştır. Cevaplayıcılara ulaşmak için Hatay Havalimanı, Ottoman Palace Otel (beş yıldızlı), Antik Beyazıt Otel (dört yıldızlı), Savon Otel (butik otel), Vakıflı Köyü (Samandağ) ve Defne ilçesi olmak üzere 6 turistik mekânda anket çalışması yapılmıştır.

Örneklem hacmini belirlemede aşağıdaki formül kullanılmıştır. $\mathrm{P}$ ve q konusunda ikincil verilere ulaşılamadığından, maksimum varyans olan 0.50 değeri seçilmiştir. p değeri; Hatay kenti hakkında olumlu söylem yayanların, q değeri ise olumsuz söylem yayanların oranını ifade etmektedir. Tolerans düzeyinin (e değeri) \%7 olması uygun görülmüştür. Güvenlik sınırı \%95 ( $\mathrm{z}=1,96)$ alınmıştır. Bu formül yardımıyla hesaplanan örneklem hacmi 196 kişidir.

$\mathrm{n}=\mathrm{p}^{*} \mathrm{q} /(\mathrm{e} / \mathrm{z})^{2}=0.50^{*} 0.50 /(0.07 / 1.96)^{2}=196$ kişi.

Örneklemin temsil yeteneğini arttırmak için mümkün olduğunca daha çok cevaplayıcıya ulaşılmaya çalışılmıştır.

Anket formunu cevaplamada gönüllülük ilkesi esas alındığından sonuçta toplam 244 kişiden veri toplanmıştır.

\section{Veri Toplama Yöntemi ve Ölçekler}

Veri toplama yöntemi olarak anket yöntemi kullanılmış olup veriler kişisel görüşme tekniği ile toplanmıştır. Anket formu hazırlanırken soruların kolayca anlaşılıp anlaşılmadığını ve istenilen bilgilere ulaştırıp ulaştırmayacağını anlamak üzere 20 cevaplayıcı üzerinde pilot araştırma yürütülmüştür. Yargı cümlelerinde ortaya çıkan farklı anlama ve algılar dikkate alınarak düzeltmeler yapılmıştır.

Anket formu 14 sorudan oluşmaktadır. İlk dört soru cevaplayıcıların, ne kadar süredir kentte oldukları, ziyaret sıklığı, amacı ve seyahate kiminle çıktıklarına ilişkin sorulardır. Beşinci soru; destinasyon kişiliğini ölçen kişilik özellikleri ile ilgilidir. Soruda 33 özellik yer almaktadır. Altıncı soru, Hatay'nın genel imajı, atmosferi ve çekici kılan ayırt edici özelliği ile ilgili- dir. Yedinci soru; 21 nitelikten oluşan bilişsel marka imajı ölçeği sorusudur. Sekizinci soru; dört duyguyu içeren duygusal marka imajı ile ilgilidir. Bu soruda 5 puanlı semantik farklılıklar ölçeği kullanılmıştır. Dokuzuncu soruda; "Turistik bir yer olarak Hatay'1 arkadaşlarınıza veya akrabalarınıza tavsiye eder misiniz?” sorusu sorulmuştur. Onuncu soru; Hatay'ı tercih etmede etkili olan bilgi kaynakları ile ilgilidir. On birinci soruda; Hataylılarla etkileşiminin bıraktığı izlenim açık uçlu soru şeklinde sorulmuştur. On ikinci soru; Hatay'i hangi kategoriye dahil ettikleriyle ilgili olup, cevap şılkları olarak; Orta Doğu şehri, Tarih ve Kültür şehri vb. seçenekler verilmiştir. On üçüncü soruda; Hatay'in daha turist canlısı bir kent olabilmesi için önerileri sorulmuştur. Bu soru açık uçludur. On dördüncü soru ise demografik özelliklerle ilgilidir. Yaş, cinsiyet, medeni durum, gelir durumu, uyruk ve öğrenim durumu sorulmuştur. Ölçek olarak genel anlamda 5’li Likert tipi ölçek kullanılmıştır. "Kesinlikle katılıyorum" ifadesine 5 puan, "Kesinlikle katılmiyorum" ifadesine 1 puan verilerek, 5'li Likert tekniğine uygun olacak şekilde bir puanlama sistemi uygulanmıştır.

Sahin ve Baloğlu'nun (2014, s. 239-265) oluşturduğu modelden yararlanan bu çalışmada destinasyon kişiliği ölçeği yazarlara benzer biçimde; Aaker (1997, s. 347-356) ve Hosany ve diğ. (2006, s. 638-642) nin çalışmalarından alınmıştır. Ancak Hatay’a özgü bazı özellikler ilave edilmiştir. Bilişsel marka imajı ölçeği olarak; Jenkins (1999, s. 1-15) tarafından geliştirilen ölçek kullanılmıştır. Kendi çalışmamıza uyarlamak için bazı nitelikler ölçekten çıkarılmıştır. Duygusal imaj ölçeği ise; Baloğlu ve McCleary (1999, s. 144152) tarafından geliştirilen bipolar ölçektir.

\section{Verilerin Analizi}

Örneklemin yapısal özelliklerine ilişkin bazı tanımlayıcı istatistikler şöyledir: Ankete katılan kişilerin \%57,0'1 kadın, \% 43,0 1 erkeklerden oluşmaktadır. Cevaplayıcıların en büyük bölümünü oluşturan \% 32,4'ünün yaşı 30-39 yaş aralığında, en küçük grubunu oluşturan grubun yaşı ise (\% 2,5'nin) 19'un altındadır. Cevaplayıcıların medeni durumlarına bakıldığında, \% 61,5’nin evli olduğu gözlenmiştir. Cevaplayıciların hemen hemen tamamı $(\% 98,8$ 'i) yerli turistlerden (TC vatandaşı) oluşmaktadır. Gelir düzeyi açısından, \%36,9 ile en büyük grubu, aylık gelir düzeyi 5000 TL. den fazla olan grup oluşturmaktadır. 
Eğitim durumları açısından, Hatay’ı ziyaret edenlerin büyük çoğunluğu (\%73,8 i) lisans veya yüksek lisans mezunudur.

Cevaplayıcıların büyük çoğunluğunun (\%79,9'unun) Hatay'da kalış süresi 1 ile 3 gün arasında değişmektedir. Yarıdan fazlası (\%54,9’u) arkadaşlarıyla seyahat ettiklerini ifade etmişlerdir. Aileleriyle seyahat edenlerin oranı ise \%23,4'tür. Ziyaretçilerin \%70,5'nin Hatay'i ilk ziyaretidir. Kente daha önce de gelenlerin oranı ise \%29,5'tur. Cevaplayıcıların önemli bir kısmı (\%48,4'ü) "Hatay’ı ziyaretinizin temel nedeni nedir?" sorusuna "yeni yerler görme" olarak cevap vermişlerdir. Yüzde 17,6’sı ise işs seyahati amacıyla gelmişlerdir.

Cevaplayıcıların ziyaret için Hatay’ı seçmesinde kullandıkları bilgi edinme kaynakları incelendiğinde; Tablo 1'e göre Hatay'ı ziyaret eden turistlerin en büyük bölümü kenti seçme kararında; arkadaş ve akrabaların söylemlerini (\%57,4 ü), ikinci grup interneti (\%26,2 si), üçüncü grup ise gazete ve dergileri (\%20,5 i) kullanmışlardır. Dolayısıyla, destinasyon hakkında bilgi edinmede kişinin yakın çevresinin ağızdan ağza iletişiminin ağırlıklı rol oynadığı görülmektedir.

Tablo 1. Turistlerin Hatay'ı Tercih Etmesinde Etkili Olan Bilgi Kaynakları

\begin{tabular}{|l|l|l|}
\hline Kaynaklar & Sayı (kişi) & Oran \\
\hline Önceki ziyaret & 35 & 14,3 \\
Seyahat acenteleri & 12 & 4,9 \\
Okuldan edinilen genel bilgiler & 9 & 3,7 \\
Televizyon programları & 43 & 17,6 \\
Gazete, dergi, seyahat kitapları & 50 & 20,5 \\
İnternet & 64 & 26,2 \\
Arkadaşlar, akrabalar vb. & 140 & 57,4 \\
Seyahat ve turizm fuarları & 13 & 5,3 \\
Diğer & 47 & 19,3 \\
\hline Toplam & 244 kişi & \\
\hline
\end{tabular}

* Cevaplayıcılara birden fazla şı işaretleyebilecekleri seçeneği verilmiştir.

Cevaplayıcıların genel olarak Hatay'la ilgili zihinlerinde oluşturdukları tek kategorilik imaj Tablo 2'de yer almaktadır. Tabloya göre; Hatay, "Tarih ve Kültür Şehri" $(\% 46,3)$ ve "Medeniyetler Beşiği" $(\% 45,1)$ olarak tanımlanmaktadır.

Destinasyon kişiliği, bilişsel ve duygusal marka imajı faktörlerinin değişkenleri ve ağızdan ağza iletişim değişkenleri açısından 5 parçalı Likert ölçeğine göre ortalama değerler Tablo 3 de gösterilmektedir. Tabloya göre; Hatay’n bir destinasyon olarak kişiliğinin en önemli özellikleri misafirperver oluşu (ort:4,30), özgün (ort:4,11), dostça (ort:4,02), nostaljik (ort:4,05), hoşgörülü (ort:4,07) ve otantik (ort:4,01) olmasıdır. Modern (ort:2,82) ve batılı (ort:2,94) olma özelliği zayıftır. Ziyaretçilerin zihnindeki bilişsel marka imajı
Hatay’n yöresel mutfağının üstünlüğü (ort:4,23) ve tarihi cazibesidir (ort:4,02). Hatay'in en önemli eksiklikleri; turist danışma bürolarının bulunmaması (ort:1,91), toplu taşıma araçlarının yetersiz olması (ort:2,02), yöresel festivallerin yapılmaması (ort:2,15), insanlarının yabanci dil bilmemeleri (ort:2,23), trafik altyapısı sorunu (ort:2,23), temizlik ve sağlığa uygunluk standartlarının yetersiz olması (ort:2,35) olarak tespit edilmiştir. Duygusal marka imajı açısından; ziyaretçilerin önemli derecede Hatay'dan keyif aldığ (ort:3,60), ortalamanın üzerinde canll, rahatlatıcı ve heyecan verici olduğu saptanmıştır. Hatay'ın turistik imajı ortalamanın üstünde ve olumludur. Ziyaretçiler yakın çevrelerine kenti tavsiye etmeye istekli olduklarını ifade etmekte ve tekrar ziyaret etmek istemektedirler. 
Tablo 2. Hatay'ın Tek Kategori ile Tanımlanması

\begin{tabular}{|l|l|l|}
\hline Tanımlayıcı Kategori & Kişi Sayısı & Oran \\
\hline Orta Doğu Şehri & 54 & 21,9 \\
Doğu ile Batının Birleşme Noktası & 61 & 25,0 \\
Doğu Şehri & 31 & 12,8 \\
Avrupa Şehri & 7 & 2,9 \\
Tatil/Dinlence Yeri & 13 & 5,3 \\
Tarih ve Kültür Şehri & 113 & 46,3 \\
Her Şeyden Biraz Var & 81 & 33,2 \\
Medeniyetler Beşiği & 110 & 45,1 \\
Diğer & 10 & 4,1 \\
\hline Toplam & 244 kişi & \\
\hline
\end{tabular}

${ }^{*}$ Cevaplayıcılara birden fazla şık işaretleyebilecekleri seçeneği verilmiştir.

Tablo 3. Kent Markasını Oluşturan Bileşenlerin Aritmetik Ortalama ve Standart Sapma Değerleri

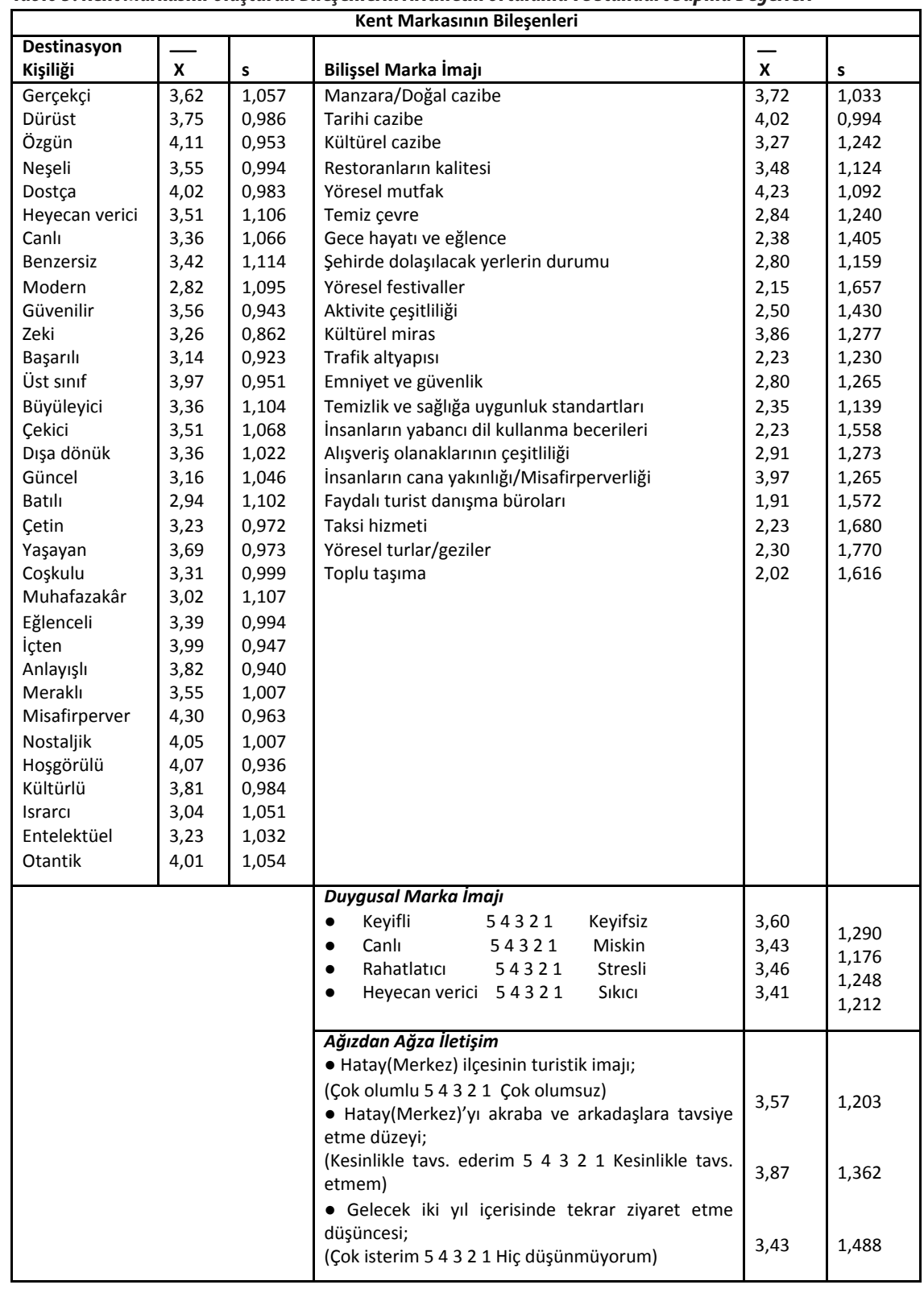




\section{Güvenilirlik Analizi}

Duygusal marka imajı ölçeği için yapılan güvenirlilik analizinde Cronbach alfa 0,89 bulunmuştur. Bilişsel marka imajı ölçeğinin Cronbach değeri 0,88 ve Destinasyon kişiliği ölçeğinin Cronbach alfa değeri 0,93’tür. $\mathrm{Bu}$ değerler, Agarwal ve Karahanna (2000, s. 678) tarafından tavsiye edilen 0.70 eşik değerinin üstündedir. $\mathrm{Bu}$ bulgulardan ölçeklerin güvenilir olduğu sonucuna varılmıştır. Ayrıca veriler girildikten sonra ham veri; kayıp veriler, uç değerler, basıklık ve çarpıklık dağılımları açısından incelenmiştir. Her bir değişkenin normal dağılım gösterip göstermediği KolmogrovSimirnov testi ile analiz edilmiş ve tüm değişkenlerin normal dağılım gösterdiği saptanmıştır.

\section{Destinasyon Kişiliği, Bilişsel ve Duygusal Marka İmajının Başkasına Tavsiye Etme Niyeti Üzerindeki Etkisi-Regresyon Analizi -Tüm Örneklem}

Başkalarına tavsiye etme niyetine etki eden faktörleri saptamak üzere tüm örneklem üzerinde yapılan basamaklı (stepwise) regresyon analizinde; kriter değişken "başkalarına tavsiye etme niyeti", tahmin değişkenleri ise "destinasyon kişiliği", "bilişsel marka imajı" ve "duygusal marka imajı" olarak belirlenmiştir. Destinasyon kişiliği, bilişsel ve duygusal marka imajı çok boyutlu ölçüldüğü için ölçek ortalamaları dikkate alınmıştır.
Tablo 4'te düzeltilmiş $\mathrm{R}^{2}$ değerine bakılarak tahmin değişkenlerinin "başkalarına tavsiye etme niyetindeki” değişimi \% 20 oranında açılkladığ görülmektedir. Durbin-Watson değerinin 1,956 olması ise "oto korelasyonun önemsiz" olduğunu göstermektedir. F değerinin istatistiksel açıdan anlamlı olduğu; yani tahmin değişkenlerinin kriter değişkendeki değişimi belirlediği ve modelin kullanılmasının uygun olduğu saptanmıştır. Ayrıca Varyans Enflasyon Faktörü (VIF) 10'un altında, tolerans istatistikleri de 0,2'nin üstünde olduğundan tahmin değişkenleri arasında mükemmel doğrusal bir ilişki bulunmamaktadır.

Tablo 4’te gösterilen analiz sonuçlarına göre; duygusal marka imajı ( $\beta: 0,40$; anl:0,00), ve destinasyon kişiliği ( $\beta$ : 0,17; anl:0,00) anlamlı bulunmuştur. Buna göre olumlu yönde başkalarına tavsiye etme niyetinde, duygusal marka imajının ve destinasyon kişiliğinin önemli bir rol oynadığı söylenebilir. Dolayısıyla $\mathrm{H}_{2}$ ve $\mathrm{H}_{3}$ hipotezleri kabul edilmiştir. Bilişsel marka imajının ise başkalarına tavsiye etme niyeti üzerinde bir etkisi bulunamamıștır. $\mathrm{H}_{1}$ hipotezi red edilmiştir. Ayrıca duygusal marka imajının, başkalarına tavsiye etme niyetini destinasyon kişiliğine göre daha fazla etkileyen (\%40 oranında) faktör olduğu görülmektedir.

Tablo 4. Kent Markasının Bileşenleri olan Destinasyon Kişiliği, Duygusal Marka Imajı ve Bilişsel Marka İmajı Faktörlerinin Kenti Başkalarına Tavsiye etme Niyeti Üzerine Etkisi-Regresyon Analizi

\begin{tabular}{|l|l|l|l|l|l|}
\hline \multicolumn{1}{|c|}{ Bağımsız Değişkenler } & \multicolumn{1}{|c|}{ B } & Std. Hata & Beta $(\beta)$ & \multicolumn{1}{|c|}{ t } & Anl.Düz. \\
\hline Sabit & $-7,382$ & 0,057 & & 0,000 & 1,000 \\
\hline Duygusal marka imaj1 & 0,407 & 0,058 & 0,40 & 7,063 & $0,00^{* * *}$ \\
\hline Destinasyon kişiliği & 0,171 & 0,058 & 0,17 & 2,973 & $0,00^{* * *}$ \\
\hline Düzeltilmiş $\mathrm{R}^{2}=0,20$ & $\mathrm{~F}=31,908$ & Sig.F $=0,000 \quad$ Dur-W $=1,956$ \\
\hline
\end{tabular}

Kriter Değişken: Başkalarına tavsiye etme niyeti

*Anlm.düz: 0,10; ** Anlm.düz: 0, 05; *** Anlm.düz: 0, 01

\section{Ziyaret Sıklığı ve Ziyaret Amacına göre Farklı Grupların Öne Çıkan Özellikleri: Regresyon Analizi - Alt Örneklemler}

Pazar bölümleme, modern pazarlama anlayışının temel uygulamalarından biridir. Bu uygulama; pazarın belli kıstaslara göre bölümlere ayrılmasını ve her pazar bölümüne daha etkin pazarlama stratejilerinin uygulanmasını, pazarı daha iyi tanımayı ve kitlesel pazara oranla çok daha fazla müşteri tatmini sağlar.
Bu noktadan hareketle, örneklem İlk kez/Tekrar Gelenler ve Ziyaret Amacına göre gruplara ayrılmış ve çalışmanın modeli her grupta ayrı ayrı test edilmiştir. Böylece grupların farklı ve öne çıkan eğilimleri belirlenerek daha uygun stratejilerin önerilmesi mümkün olabilecektir. Bu bağlamda 10 alt grup saptanmıştır. Yapılan basamaklı regresyon analizi sonuçları detaylarıyla Tablo 5’te gösterilmektedir. 
Tablo 5. Ziyaret Sıklığı ve Ziyaret Amacına göre Farklılaşan Gruplarda; Destinasyon kişiliği, Duygusal ve Bilişsel Marka Imajının Başkalarına Tavsiye Etme Niyetine Etkisi-Regresyon Analizleri

\begin{tabular}{|c|c|c|c|c|c|c|c|}
\hline \multicolumn{4}{|c|}{ 1x1 Grubu: Illk Kez ve Tatil Amaçlı Gelenler } & \multicolumn{4}{|c|}{ 2x1 Grubu: Tekrar ve Tatil Amaçlı Gelenler } \\
\hline Bağımsız Değ. & Beta & $\mathrm{t}$ & Anl.Düz & Bağımsız Değ. & Beta & $\mathrm{t}$ & Anl.Düz. \\
\hline Sabit & & 0,847 & 0,41 & Sabit & & $-1,342$ & 0,199 \\
\hline Bilişsel marka imajı & 0,53 & 2,392 & $0,03 * *$ & Bilişsel marka imajı & 0,56 & 2,634 & $0,01 * * *$ \\
\hline \multicolumn{4}{|c|}{$\begin{array}{|llll|}\text { Düz. } \mathrm{R}^{2}=0,23 & \mathrm{~F}=5,724 & \text { Sig.F=0,03 } & \mathrm{DW}=1,801 \\
\mathrm{~N}=16 \text { kişi } & & & \\
\end{array}$} & \multicolumn{4}{|c|}{$\begin{array}{|llll|}\text { Düz. } \mathrm{R}^{2}=0,27 & \mathrm{~F}=6,936 & \text { Sig.F=0,01 } & \mathrm{DW}=1,577 \\
\mathrm{~N}=17 \text { kişi } & & & \\
\end{array}$} \\
\hline \multicolumn{4}{|c|}{$\begin{array}{l}\text { 1x2 Grubu: ilk Kez ve Eğlence /Heyecan Amaçlı } \\
\text { Gelenler }\end{array}$} & \multicolumn{4}{|c|}{$\begin{array}{l}\text { 2x2 Grubu: Tekrar ve Eğlence /Heyecan Amaç } \\
\text { Gelenler }\end{array}$} \\
\hline \multicolumn{4}{|c|}{$\begin{array}{l}\text { Bu gruptaki kişi sayısı çok az ( } \mathrm{N}=4 \text { kişi) olduğundan } \\
\text { regresyon analizi yapılamamıştır. }\end{array}$} & \multicolumn{4}{|c|}{$\begin{array}{l}\text { Bu gruptaki kişi sayısı çok az ( } \mathrm{N}=8 \text { kişi) olduğunda } \\
\text { regresyon analizi yapılamamıştır. }\end{array}$} \\
\hline \multicolumn{4}{|c|}{$\begin{array}{l}\text { 1x3 Grubu: Ilk Kez ve Yeni Yerler Görme Amaçli } \\
\text { Gelenler }\end{array}$} & \multicolumn{4}{|c|}{$\begin{array}{l}\text { 2×3 Grubu: Tekrar ve Yeni Yerler Görme Amaç } \\
\text { Gelenler }\end{array}$} \\
\hline Bağımsız Değ. & Beta & $\mathrm{t}$ & Anl.Düz & Bağımsız Değ. & Beta & $\mathrm{t}$ & Anl.Düz. \\
\hline Sabit & & 0,169 & 0,866 & Sabit & & $-0,428$ & 0,675 \\
\hline Duygusal marka imajı & 0,37 & 4,220 & $0,00^{* * *}$ & Destinasyon kişiliği & 0,58 & 2,793 & $0,01 * * *$ \\
\hline Destinasyon kişiliği & 0,24 & 2,708 & $0,00 * * *$ & & & & \\
\hline \multicolumn{4}{|c|}{$\begin{array}{|llll|}\text { Düz. } R^{2}=0,19 & F=13,376 & \text { Sig. } F=0,00 & D W=1,832 \\
N=101 \text { kiși } & & & \\
\end{array}$} & \multicolumn{4}{|c|}{\begin{tabular}{|llll} 
Düz. $\mathrm{R}^{2}=0,29$ & $\mathrm{~F}=7,802$ & Sig.F $=0,01$ & $\mathrm{DW}=1,714$ \\
$\mathrm{~N}=17$ kiși & & & \\
\end{tabular}} \\
\hline \multicolumn{4}{|c|}{ 1x4 Grubu: Illk Kez ve İş Seyahati Amaçlı Gelenler } & \multicolumn{4}{|c|}{ 2x4 Grubu: Tekrar ve İş Seyahati Amaçlı Gelenler } \\
\hline Bağımsız Değ. & Beta & $\mathrm{t}$ & Anl.Düz & Bağımsız Değ. & Beta & $\mathrm{t}$ & Anl.Düz. \\
\hline Sabit & & $-0,384$ & 0,704 & Sabit & & $-1,076$ & 0,305 \\
\hline Duygusal marka imaj1 & 0,53 & 3,317 & $0,00 * * *$ & Destinasyon kişiliği & 0,78 & 4,190 & $0,00 * * *$ \\
\hline \multicolumn{4}{|c|}{$\begin{array}{|llll|}\text { Düz. } \mathrm{R}^{2}=0,26 & \mathrm{~F}=11,002 & \text { Sig. } \mathrm{F}=0,00 & \mathrm{DW}=1,908 \\
\mathrm{~N}=30 \text { kişi } & & & \\
\end{array}$} & \multicolumn{4}{|c|}{$\begin{array}{|llll|}\text { Düz. } \mathrm{R}^{2}=0,58 & \mathrm{~F}=17,554 & \text { Sig. } \mathrm{F}=0,00 & \mathrm{DW}=2,597 \\
\mathrm{~N}=13 \text { kişi } & & & \\
\end{array}$} \\
\hline \multicolumn{4}{|c|}{$\begin{array}{l}\text { 1x5 Grubu: Illk Kez ve Diğer Amaçlarla (örn.Askerlik..) } \\
\text { Gelenler }\end{array}$} & \multicolumn{4}{|c|}{$\begin{array}{l}\text { 2x5 Grubu: Tekrar ve Diğer Amaçlarla (örn.Askerlik. } \\
\text { Gelenler }\end{array}$} \\
\hline Bağımsız Değ. & Beta & $\mathrm{t}$ & Anl.Düz & Bağımsız Değ. & Beta & $\mathrm{t}$ & Anl.Düz. \\
\hline Sabit & & 0,940 & 0,359 & Sabit & & $-0,412$ & 0,686 \\
\hline Duygusal marka imajı & 0,63 & 3,540 & $0,00 * * *$ & Duygusal marka imajı & 0,62 & 3,088 & $0,00 * * *$ \\
\hline \multicolumn{4}{|c|}{$\begin{array}{|llll|}\text { Düz. } R^{2}=0,36 & F=12,532 & \text { Sig.F }=0,00 & \text { DW }=2,158 \\
N=21 & & & \\
\end{array}$} & \multicolumn{4}{|c|}{$\begin{array}{llll}\text { Düz. } R^{2}=0,34 & F=9,537 & \text { Sig.F }=0,00 & D W=2,493 \\
N=17 & & & \\
\end{array}$} \\
\hline
\end{tabular}

Kriter Değişken: Başkalarına tavsiye etme niyeti

*Anlm.düz: 0,10; ** Anlm.düz: 0,05; *** Anlm.düz: 0, 01

$1 x 1$ Grubu: İlk Kez ve Tatil Amaçlı Gelenler; daha çok bilişsel değerlendirmelerde bulunmakta ve bu değerlemelerin olumlu olması halinde kenti başkala- rına tavsiye etmektedirler. Dolayısıyla, kentin fiziksel ve yapısal niteliklerinin bu grup için önemli olduğu görülmektedir. 
$1 x 2$ Grubu: Illk Kez ve Eğlence/Heyecan Amaçlı Gelenler; çok az sayıdadır. Dolayısıyla kentin turizm açısından eğlence ve heyecan arayanlar için pek uygun olmadığ 1 algısından söz edilebilir.

$1 x 3$ Grubu: İlk Kez ve Yeni Yerler Görme Amaçlı Gelenler; en büyük grubu oluşturmaktadır. Bu grubun kentte yaşadığ 1 duygusal tatminler ve kentin kişiliğinin olumlu olması kenti başkalarına tavsiye etmelerine yol açmaktadır.

$1 x 4$ Grubu: İlk Kez ve İşs Seyahati Amaçlı Gelenler; yaşadıkları duygusal tatminler sonucunda kenti başkalarına da tavsiye etmektedirler.

$1 x 5$ Grubu: İlk Kez ve Diğer Amaçlarla (örn.Askerlik..) Gelenler; bir önceki gruba benzer biçimde yaşadıkları duygusal tatminler sonucunda kenti başkalarına da tavsiye etmektedirler.

$2 x 1$ Grubu: Tekrar ve Tatil Amaçlı Gelenler; daha öncesinden gelerek bir deneyim yaşamış gruptur. Ancak halen kentin fiziksel ve yapısal nitelikleri üze- rinde durmakta ve tatilde rahatsızlik veren sorunlarla karşılaşmak istememektedirler. Bu niteliklerin olumlu olması, kenti başkalarına tavsiye etmelerinin önünü açmaktadır.

$2 \times 2$ Grubu: Tekrar ve Eğlence/Heyecan Amaçlı Gelenler; çok az sayıdadır.

$2 \times 3$ Grubu: Tekrar ve Yeni Yerler Görme Amaçlı Gelenler; kentin kişiliğinden etkilenerek başkalarına tavsiye etmektedirler.

$2 x 4$ Grubu: Tekrar ve İş Seyahati Amaçlı Gelenler; bir önceki gruba benzer biçimde kenti başkalarına tavsiye etmelerinde, destinasyonun kişiliği en önemli rolü oynamaktadır.

$2 x 5$ Grubu: Tekrar ve Diğer Amaçlarla (örn.Askerlik..) Gelenler; yaşadıkları duygusal tatminler sonucunda kenti başkalarına da tavsiye etmektedirler.

Bulguların özet sonuçları Tablo 6'da sunulmaktadır. Bu sonuçlardan hareketle $\mathrm{H}_{4}$ hipotezi kabul edilmiştir.

Tablo 6. Özet Sonuç Tablosu

\begin{tabular}{|l|l|l|l|l|l|}
\hline Alt Gruplar & Anlamlı Faktörler & $\begin{array}{l}\text { Beta } \\
\text { değeri }\end{array}$ & Gruplar & Anlamlı Faktörler & $\begin{array}{l}\text { Beta } \\
\text { değeri }\end{array}$ \\
\hline $1 \times 1$ Grubu & Bilişsel marka imajı & 0,53 & $2 \times 1$ Grubu & Bilişsel marka imajı & 0,56 \\
\hline $1 \times 2$ Grubu & -- & & $2 \times 2$ Grubu & -- & \\
\hline $1 \times 3$ Grubu & $\begin{array}{l}\text { Duygusal marka imajı } \\
\text { Destinasyon kişiliği }\end{array}$ & $\begin{array}{l}0,37 \\
0,24\end{array}$ & $2 \times 3$ Grubu & Destinasyon kişiliği & 0,58 \\
\hline $1 \times 4$ Grubu & Duygusal marka imajı & 0,53 & $2 \times 4$ Grubu & Destinasyon kişiliği & 0,78 \\
\hline $1 \times 5$ Grubu & Duygusal marka imajı & 0,63 & $2 \times 5$ Grubu & Duygusal marka imajı & 0,62 \\
\hline
\end{tabular}

\section{Araştırma Bulguları}

Bu çalışmada, bir kenti başkalarına tavsiye etme niyetini belirleyen anahtar marka bileșenlerinden bilișsel marka imaj1, duygusal marka imajı ve destinasyon kişiliğinin etkilerini test etmek ve bu etkilerin ziyaret amacına ve sıklığına göre değişip değişmediğini tespit etmek amacıyla ampirik bir araştırma yapılmıştır.

Araştırmanın gerçekleştirildiği örneklemin yapısı özet olarak şu şekildedir: Cevaplayıcıların yarıdan biraz fazlası kadındır. En büyük bölümü oluşturan grubun yaşı 30-39 yaş aralığındadır. Gelir düzeyi açısından, en büyük grubu, aylık gelir düzeyi 5000 TL. den fazla olan grup oluşturmaktadır. Eğitim durumları açısından, Hatay'ı ziyaret edenlerin büyük çoğunlu- ğu lisans veya yüksek lisans mezunudur. Hatay’ı ziyaret eden turistlerin en büyük bölümü kenti seçme kararında; arkadaş ve akrabaların söylemlerini esas almışlardır. Hatay, "Tarih ve Kültür Şehri” ve "Medeniyetler Beşiği” olarak tanımlanmaktadır. Hatay’ın en önemli kişilik özellikleri; misafirperver oluşu, özgün, dostça, nostaljik, hoşgörülü ve otantik olmasıdır. Modern ve batılı olma özelliği zayıftır. Ziyaretçilerin zihnindeki bilişsel marka imajı Hatay'ın yöresel mutfağının üstünlügü ve tarihi cazibesidir. Hatay'ın en önemli eksiklikleri; turist danışma bürolarının bulunmaması, toplu taşıma araçlarının yetersiz olması, yöresel festivallerin yapılmaması, insanlarının yabanc1 dil bilmemeleri, trafik altyapısı sorunu, temizlik ve sağlığa uygunluk standartlarının yetersiz olması ola- 
rak tespit edilmiştir. Duygusal marka imajı açısından; ziyaretçilerin önemli derecede Hatay'dan keyif aldığı, canlı, rahatlatıcı ve heyecan verici olduğu saptanmıştır. Ziyaretçiler yakın çevrelerine kenti tavsiye etmeye istekli görünmekte ve tekrar ziyaret etmek istemektedirler.

Örneklemin tümü üzerinde yapılan regresyon analizi sonuçlarına göre; duygusal marka imajı $(\beta: 0,40)$, ve destinasyon kişiliği $(\beta: 0,17)$ faktörlerinin, başkalarına tavsiye etme niyeti üzerinde olumlu yönde bir etkiye sahip oldukları görülmüştür. Dolayısıyla, duygusal marka imajının ve destinasyon kişiliğinin kenti tavsiye etmede önemli bir rol oynadığı söylenebilir. Bilişsel marka imajının ise başkalarına tavsiye etme niyeti üzerinde bir etkisi bulunamamıştır. Ayrıca duygusal marka imajının, kenti başkalarına tavsiye etme niyetini destinasyon kişiliğine göre daha fazla etkileyen (\%40 oranında) faktör olduğu anlaşılmaktadır. Kişilerin bir kentin marka avukatlığını yapmalarında en etkili değişkenin kişilerin kentle ilgili yaşadıkları olumlu duygular olduğu söylenebilir. Bu bulgu, Mendes, Do Valle ve Guerreiro (2011) ve Ramkissoon, Uysal ve Brown (2011) tarafından yapılan araştırma sonuçlarıyla da örtüşmektedir.

Örneklemin alt grupları üzerinde yapılan regresyon analizinde ise; ilk kez ve tekrar tatil amaçlı kente gelen kişilerde bilişsel imajın önemli olduğu dikkat çekmektedir. Kentin konforu, ulaşımı ve fiziki alt yapısı ile ilgili izlenimlerin markanın avukatlığını yapmada rol oynadığı görülmektedir. Duygusal imajın gücü ise ziyaret sıklı̆ğına ve amacına göre değişmektedir. Özellikle ilk kez iş seyahati ve diğer amaçlarla gelenlerde duygular ağır basmaktadır. Ancak iş seyahati için tekrar gelenlerde duygular yerini ağırlıklı olarak destinasyon kişiliğine bırakmaktadır. Aynı şekilde yeni yerler görme amacıyla ilk kez gelenlerde duygular önemli iken tekrarlayan gelişlerde destinasyon kişiliği öne çıkmaktadır. Kişilerin kenti daha iyi tanıdıkça kentle ilgili bilgileri arttığından duygusal imajdan ilk gelenler kadar yoğun etkilenmedikleri söylenebilir. Sonuç olarak kent markası boyutlarının etkilerinin gruplara göre farklılık gösterdiği anlaşılmaktadır. $\mathrm{Bu}$ bulgu; Sahin ve Baloğlu (2014)'nun bulgularını da desteklemektedir. Eğlence ve heyecan amaçlı gelenlerin sayısı ise yok denecek kadar azdır.

Anketin son kısmında cevaplayıcılara, kente ait genel imaj ve Hataylılarla etkileşiminin bıraktığ 1 iz- lenimlerinin ne olduğu, açı uçlu sorular şeklinde yöneltilmiştir. $\mathrm{Bu}$ açık uçlu soruların içerik analizi sonucunda, kente ait genel imajın tarihi mekânları ve yöresel mutfağı olduğu saptanmıştır. Hatay’a özgü kültürel miras, dinlerin kardeşliği, doğal güzellikler, insanlarının sıcak ve misafirperver oluşları ve kentin otantik yapısı öne çıkan özelliklerdir. Kentin atmosferinin canl, neşeli, tarih kokan ve sıcak olduğu ifade edilmiştir. Hatay’’ çekici kılan kendine has özellikler arasında tarihi mekânlar ve yemekleri en çok vurgulanan ayırt edici özellikler olmuştur. Popüler turistik aktivitelere baktığımızda ise yöresel mutfak en önde gelmektedir. Çoğu turistin kente yapılan ziyaretten memnun kaldığı, yaklaşık olarak yüzde doksanının Hataylıların kendi üzerlerinde olumlu etki bıraktığı yanıtı alınmıştır.

Benzer şekilde, ankete katılan turistlere yine açı uçlu soru şeklinde turizm açısından önerileri ve eleştirileri sorulmuştur. Kentin geliştirilmesine yönelik önerilerin başında; kentin tarihi dokusunun korunmasına yönelik yenileme ve bakım çalışmalarının yapilması gelmektedir. Kentin ve kentteki turistik mekânların tanıtımının arttırılması ve turistlere yönelik günlük turların yapılması diğer öneriler olarak ifade edilmiştir.

\section{Araştırmanın Genel Sonuç ve Önerileri}

Güçlü kent markaları, kültürel bir değer yaratmakla kalmayıp, bir ülkenin ürünlerinin satışlarının artmasına da katkı sağlamaktadır. Aşağıda, güçlü kent markaları oluşturmanın etkin yollarını ortaya koymak amacıyla yapılan araştırmanın bulgularından hareket edilerek yöneticiler ve araştırmacılar için anlamlı öneriler sunulmaktadır.

\section{Yöneticiler için öneriler:}

Bu çalışma Türkiye'deki tüm kentler için uygulanabilir. Kullanılan standart ölçekler, kamu yöneticileri ve turizm yatırımcıları için önemli bir araç niteliği taşımaktadır. Böylece kentin hangi özelliklerinin öne çıarılması ve geliştirilmesi hangilerinin eksikliklerinin tamamlanması ve iyileştirilmesi gerektiği saptanarak daha güçlü kent markası oluşturulabilir. Bu bağlamda araştırmada uygulanan yöntembilim rehber yol niteliğindedir. Turist canlısı bir kent yaratmak için çaba harcayan Hatay ve Türkiye turizm otoriteleri için önemli geri bildirimler sağlamaktadır. Böylece, otoritelerin turistlerin bakış açlarını ve de- 
neyimlerini anlamalarına ve onların beklentilerine daha uygun, spesifik ve kaliteli hizmet sunmalarına katkı sağlayacaktır.

Zaman içinde kentin ürün ve hizmetlerinin kalitesi yükselebilir ya da düşebilir. Bu açıdan kamu kurumları ve sivil toplum örgütleri tarafından sürekli bir izlemenin yapılması ve ortaya çıkan zayıflıkların giderilmesi için gerekli yatırımların yapılmasında marka imajının bozulmaması için yarar vardır.

Kentin tanitımının ve olumlu marka imajının yarat1labilmesi için, yoğun ve hayli maliyetli reklam kampanyaları ve halkla ilişkiler çabalarına gereksinim vardır. Bu bağlamda, yerel halk ve turizm işletmeleriyle işbirliğinin yapılması yararlı bir strateji olacaktır. Bu strateji, ev sahipleri olarak nitelendirdiğimiz bu grupların kendilerini kent markasının bir parçası gibi görmelerini, hissetmelerini ve daha içten, samimi, motivasyonlu bir biçimde kent markasını güçlendirmeye yardımcı olmalarını sağlayacaktır. Yerel halk ve özel sektör işletmeleri arasındaki bu işbirliği turistlerin gözünde kentin çekiciliğini arttıracaktır. Özellikle turistlerin konaklayacakları, alışveriş yapacakları ve gezip görmek istedikleri mekanların temiz tutulması önemlidir. Reklam ve tanıtımlarda ne söylenmiş olursa olsun, turistin gördüklerini aklında tutacağını ve başkalarıyla yaşadığı deneyimi paylaşacağını unutmamak gerekir. Dolayısıyla kent için hazırlanmış reklam sloganlarının kentin gerçek imajını birebir yansıtması gerekmektedir.

Destinasyon kişiliğini yansitacak, tiyatro etkinlikleri, broşürler, ufak kent sembolü hediyelikler de önerilebilir. $\mathrm{Bu}$ argümanlar turistlerin zihninde daha kalıc1 olmayı sağlayacak ve anonim bir kimlik yerine kenti hatırlamayı kolaylaştıracaktır.

Kentte turistin gelişinden gidişine kadarki süreçte gereksinim duyduğu her hizmeti birbiriyle koordinasyonlu bir biçimde zincir olarak düzenleyen uygulamalar da marka kentlerin gücünü arttırmaktadır. Daha düşük fiyatlarla ve paket olarak sunulan, transfer, otel, kent içi-dışı turlar, lokanta hizmetleri turistin işini kolaylaştıracak ve memnuniyet yaratabilecektir.

Yerel yönetimler, ev sahibi niteliğindeki gruplara eğitim programları düzenleyebilirler. Bu eğitim programları gruplar arasındaki çıkar çatışmalarının ya da bir grubun baskın olmasının önüne geçilmesi ve ortak çıkarlar çerçevesinde davranılmasının da önünü açacaktır.

Yerel yönetimler ve özel sektör, duygusal imaja önem vermelidirler. Akla hitap edildiği kadar kalbe de hitap edilmesi önemlidir. Dolayısıyla kent markasının iletişim stratejileri hazırlanırken potansiyel turistlerde pozitif duyguların ve hislerin yaratılmasına özen gösterilmelidir.

Ayrıca, kent markası yaratılırken markanın tüm bileşenlerinin holistik (bütünsel) bir biçimde ele alınması ve bu bileşenler arasında tutarlılık olması önemlidir.

\section{Araştırmacılar için öneriler:}

Araştırma zaman ve ekonomik kısıtlar çerçevesinde gerçekleştirilmiştir. Aynı zamanda coğrafik olarak üç ilçe ile sınırlıdır. Gelecek araştırmaların farklı coğrafik alanlarda yapılması ve farklı faktörleri test etmesi güçlü kent markası oluşturma yöntemlerinin daha iyi anlaşılmasına katkı sağlayacaktır.

\section{Kaynakça}

Aaker, J. (1997). Dimensions of brand personality. Journal of Marketing Research, 34, 347-356.

Agarwal, R., Karahanna, E. (2000). 'Time Flies When You're Having Fun: Cognitive Absorption and Beliefs about Information Technology Usage, MIS Quarterly, 24(4), s.678.

Alvarez, M. ve Korzay, M. (2011). Turkey as a heritage tourism destination: The role of knowledge. Journal of Hospitality Marketing \& Management, 20(3/4), 425-440.

Bagozzi, R.P. ve Dholakia, U.M. (2006). Antecedents and purchase consequences of customer participation in small group brand communities. International Journal of Research in Marketing, 23, 45-61.

Baloğlu, S. ve Brinberg, D. (1997). Affective images of tourism destinations. Journal of Travel Research, 35(4), 11-15. 
Baloğlu, S. (1999). A path analytic model of visitation intention involving information sources, socio demographic and trip characteristics of international travelers. Journal of Travel \& Tourism Marketing, 3(3), 221-233.

Baloğlu, S. ve McCleary, K. (1999). US international pleasure travelers' image of four Mediterranean destinations: A comparison of visitors and nonvisitors. Journal of Travel Research, 38(2), 144-152.

Baş, T. ve Akturan, U. (2008). Nitel Araştırma Yöntemleri, Seçkin Yayıncılık.

Beerli, A. ve Martin, J. (2004). Tourists' characteristics and perceived image of tourist destinations: A quantitative analysis- a case study of Lanzarote, Spain. Tourism Management, 25, 623-636.

Braun-LaTour, K. \& LaTour, M. (2005). Transforming consumer experience. Journal of Advertising, 34(3), 19-30.

Ekinci Y., Sirakaya, E. ve Baloğlu, S. (2007). Host image and destination personality. Tourism Analysis, 12, 433-446.

Fan, Y. (2015). Branding the Nation: What is being branded. Journal of Vacation Marketing, 12, 1.

Fodness, D. ve Murray, B. (1999). A model of tourist information search behavior. Journal of Travel Research, 37, 220-230.

Fournier, S. (1998). Consumers and their brands: Developing relationship theory in consumer research. Journal of Consumer Research, 24, 343-373.

Gonzales, A.M. ve Bello, L. (2002). The construct "lifestyle" in market segmentation: The behavior of tourist consumers. European Journal of Marketing, $36,51-85$.

Gursoy, D., Bonn, M. ve Chi, C. (2010). An examination of general, nondestination-specific versus destination-specific motivational factors. Journal of Hospitality Marketing \& Management, 19(4), 340-357.
Hosany, S., Ekinci, Y. ve Uysal, M. (2006). Destination image and destination personality: An application of branding theories to tourism places. Journal of Business Research, 59(5), 638-642.

http://www.mku.edu.tr.

http://www.google.com.

Jenkins, O. (1999). Understanding and measuring tourist destination images. International Journal of Tourism Research, 1(1), 1-15.

Kavak B. (2008). Pazarlama ve Pazar AraștırmalarıTasarım ve Analiz, Detay Yayıncılık, Ankara.

Kavaratzis, M. (2009). Cities and their brands: Lessons from corporate branding. Place Branding and Public Diplomacy, 5(1), 26-37.

Kim, K., Hallab, Z. ve Kim, J. (2012). The moderating effect of travel experience in a destination on the relationship between the destination image and the intention to revisit, Journal of Hospitality Marketing \& Management, 21(5), 486-505.

Kotler, P. ve Gertner, D. (2002). Country as brand, product, and beyond: a place marketing and brand management perspective. Journal of Brand Management, 9(4-5), 249-261.

Landry, C. (2006). The art of city-making. Sterling, VA: Earthscan.

Lawson, F. ve Baud-Bovy, M. (1977). Tourism and Recrational Development, London, England: Architectural Press.

Mendes, J., Do Valle, P. ve Guerreiro, M. (2011). Destination image and events: A structural model for the Algarve case. Journal of Hospitality Marketing \& Management, 20(3/4), 366-384.

Merrilees, B., Miller, D. ve Herington, C. (2012). Multiple stakeholders and multiple city brand meanings. European Journal of Marketing, 46(7-8), 1032-1047. 
Morgan, N., Pritchard, A. ve Pride, R. (2004). Destination branding: Creating the unique destination proposition. Oxford, England: Butterworth Heinemann.

Netemeyer, R. G., Bearden, W. O. \& Sharma, S. (2003). Scaling Procedures: Issues and Applications. Sage Publications, s.59-69.

Noni, I.D., Orsi, L. ve Zanderighi, L. (2014). Attributes of Milan influencing city brand attractiveness. Journal of Destination Marketing \& Management, 3, 218-226.

Pawaskar, P. ve Goel, M. (2014). A conceptual model: Multisensory marketing and destination branding. Procedia Economics and Finance, 11, 255-267.

Ramkissoon, H., Uysal, M. \& Brown, K. (2011). Relationship between destination image and behavioral intentions of tourists to consume cultural attractions. Journal of Hospitality Marketing \& Management, 20(5), 575-595.

Sahın, S., S. Baloğlu (2011). Brand personality and destination image of Istanbul. Anatolia: An International Journal of Touirism \& Hospitality Research, 22(1), 69-88.
Sahın, S. ve S. Baloğlu (2014). City branding: Investigating a brand advocacy model for distinct segments, Journal of Hospitality Marketing \& Management, 23, 239-265.

Sevin, H.E. (2013). Understanding cities through city brands: City branding as a social and semantic network. Cities, http://dx.doi.org/10.1016/j.cities.2014.01.003

Sirkaya, E. ve Woodside, A. (2005). Building and testing theories of decision making by travelers. Tourism Management, 26, 815-832.

Uzama A. (2012). Yokoso! Japan: Classifying Japan tourists to Japan for market segmentation. Journal of Hospitality Marketing \& Management, 21(2), 132154.

Yazıcıoğlu, Y. ve Erdoğan, S. (2004). SPSS Uygulamalı Bilimsel Araştırma Yöntemleri. Ankara: Detay Yayincilik. 